\title{
Stitch after stitch. Inspiring arpilleras, amateur freedom, intimate activism and letting go
}

\section{Author: Daniela Lara Espinoza $\vee$, University of Edinburgh, UK}

Daniela Lara Espinoza is a Chilean embroiderer/researcher, currently studying for a PhD at the Edinburgh College of Art.

\begin{abstract}
As a Chilean embroiderer/researcher, the exhibition Threads, War and Conflict was close to my practice, since I research how embroidery can be used to elicit conversations on difficult sociopolitical matters. Participating in the workshop 'Letters to Arpilleristas' was an opportunity to express creativity by making a piece of textile art. Still, at the same time, it was challenging because we knew from the start that the piece was not to be kept for our contemplation. This brief auto-ethnographic essay reflects on needlework, labouriousness, self-care and letting go, with regard to the pieces created at the workshop.
\end{abstract}

Keywords: needlework, laboriousness, auto-ethnography, textile art, self-care

As a Chilean bead embroiderer and PhD researcher, I became interested in this exhibition and workshops because, at the time, I was exploring the use of craft-related practices to confront systems of oppression that mostly affect women. Part of my research was focused on investigating the arpilleras made during the Chilean dictatorship, and I was also interested in experimenting with collaborative textile work, observing its potential in reaching wider audiences to expose and denounce human rights violations.

The workshops were an opportunity to express creativity through textile art. They were also challenging because of their collaborative aspect. The artworks made by the participants were meant to be part of a larger piece for the Conflict Textile archive. Thus, ahead of us participants was the challenge to design a textile piece inspired by personal (sensitive) topics, dedicate hours of stitching and be ready to part with this small creation. This article proposes a reflection on the inspirations and use of stitching for the textiles created in the workshops, with a special focus on my (dis)connection with the arpilleras as a Chilean contemporary textile artist. 


\section{Atrophied memories of the Chilean dictatorship}

Although I was born in the 1980s, while Chile was still controlled by dictator Augusto Pinochet, I do not have many memories of the dictatorship. After it was over, I also did not come to know much about it. When I was a teenager in the late 1990s and studied the dictatorship in History class, we were only told a small brief of events. For instance, on 11 September 1973 a military coup brought down the government of President Salvador Allende; the government house was bombarded and Allende committed suicide; between 1973-1989, the country was under a dictatorial regime led by Augusto Pinochet; there were killings, kidnappings, disappearances and people were tortured.

Seventeen years of history was described in summary. Oddly enough, this grave time lapse did not provoke questions for many of us, although some of my classmates denied the part about the "dictatorial" regime, mirroring their family's political stance. Even to this day, some Chileans deny the dictatorship and all its atrocities.

Tomás Moulian (1997) explains that a decisive element of Chile, post-dictatorship, is the compulsion to oblivion. Trauma for some, victory for others, there is an impossibility to communicate about something that is called antagonistically either: coup or pronouncement; military government or dictatorship; Chilean good or Chilean catastrophe (Moulian, 1997, p. 31). Moulian describes the origins and causes of fear in people oppressed by a totalitarian regime. He uses the concept of terror, claiming that terror pushed Germans to overlook Auschwitz, and many Chileans to deny knowing about the mass tortures and the disappeared detainees (detenidos-desaparecidos) (1997, p. 22).

In my case, I did not inherit that fear due to my partial ignorance, but I developed an intuition not to ask questions because I was afraid of talking to a denialist and being caught in the middle of a senseless discussion. My paternal grandfather was tortured during the dictatorship. Although I do not remember him ever talking about this, this was a disturbing story in my family. My grandfather died in 1999, and I do not think he ever even dreamed of justice.

In Chile we owe much to the movement of arpilleristas in the 1970s and 1980s, and the significance of their collective power during the dictatorship. In this sense, arpilleras were able to expose information internationally about the dictatorship's atrocities when the Chilean press was suppressed, silenced and highly controlled by the regime.

Paradoxically, until recently, I was uninformed of the existence of the arpilleras, despite identifying myself as a Chilean embroiderer. Arpilleras are more widely known abroad, with the most relevant literature being mainly in English. There might be a few reasons for this lack of knowledge in Chile. In 1983, arpilleras were banned when Pinochet's dictatorship discovered that they were not the craftwork of innocent women and understood their role in denouncing human rights violations internationally (Bacic, 2013). Another reason might be 
the lack of interest in women's artworks, especially because the original arpilleristas were very poor. Also, addressing the dictatorship in Chile presents its difficulties due to the fact that some of its defenders and former supporters are currently in positions of power.

I must admit it has been disconcerting to share the same nationality as the arpilleristas and having been unaware of their existence for so many years. The arpilleras are admirable because of how their makers aimed for social justice and were able to face the totalitarian regime, confronting cruelty, despair, fear and hunger. At the same time, however, they were also a fundamental tool to denunciate internationally the crimes committed during the Chilean dictatorship and, therefore, deserve a special place in Chilean history.

Each arpillera is an image of its maker's feelings, who used these artistic expressions as a form of relief, expressing their fears and experiences about the dictatorship. Mercedes Rowinsky-Geurtz says that words, as a classic instrument of communication, were censored and oppressed during the dictatorship; however, pen and pencil were exchanged for threads, needles and scraps of fabric to create new forms of communication (2003, p. 36). Eliana MoyaRaggio also emphasises the ability to find different channels of communication opposing censorship in the dictatorship: 'She [the arpillerista] does not use words because words have been denied her. But she can speak through a skill traditionally considered feminine, the use of thread and needle. Her needlework becomes testimony...' (1984, p. 279).

\section{Perfectionism versus calmness}

For the Letters to arpilleristas workshops, we were encouraged to reflect on the stories we saw at the exhibition and produce a 'textile testimony' thinking about the notion of home. As postgraduate students, we tend to express our thoughts and reflections through writing; therefore, it was challenging to tell a story mainly through images formed by hand-sewn pieces of fabric.

Although it was not a requirement to have any special skills to participate in the workshops, I experienced a certain level of anxiety due to the self-pressure of achieving a nice textile piece, especially since I identify myself as an embroiderer (although my expertise lies in bead-embroidery and I was not going to use that technique for my textile piece). I shared this worry at the beginning of the workshops with some of the participants. I have heard these concerns from amateur crafters many times, and I have also read similar apprehensions in several apologetic posts online: makers excusing themselves for being self-taught and, therefore, not perfect. These concerns made me wonder, how is it possible to get past the fear of not doing something technically outstanding in textile art? Or at least not funny-looking or wonky? It is as if we were meant to know how to produce perfect textile creations because using a needle should not be that difficult. Perhaps our concern was increased because our source of inspiration was the powerful arpilleras, and we intended to honour them and their historical legacy through our textile piece. 
Thankfully, textile artist Sheila Mortlock helped us, participants, to materialise our inspirations in our 'textile testimonies' forgetting the fear of doing something wrong, suggesting stitches, different threads, colours and scraps of fabrics. The ambience of the workshop was relaxed and supportive. Sheila kindly shared some of her teaching experiences, while we were all stitching our creations. I remember her observing that some of her students become so concentrated in their handiwork, silent and introspective. This was particularly impressive in young people, who were otherwise hyperactive. I recalled having read about the calming effects that needlework has on some people (Hunter, 2019). Wellesley-Smith refers to the latter as 'the relaxation response', indicating that '[p]rocesses that employ engagement between hands and brain have a way of progressing in a calm way' (2015, p. 150). The act of making alone, however, does not produce this positive effect on well-being; the activity itself has to be meaningful and relevant to the maker (Pöllänen and Weissmann-Hanski, 2019). From my experience, what makes an activity a meaningful practice is the social component. In this sense, as a researcher, I use textile art to express sociopolitical issues that might be difficult to discuss but urgent to address, such as gender inequalities, gender-based violence and the climate crisis. I chose to develop the latter through my textile testimony.

It is important to note that not everyone finds craft activities comforting (Hackney, Maughan and Desmarais, 2016; Shercliff and Twigger Holroyd, 2020). In my case, after the workshop was finished, I reflected on the differences between the process of making my 'textile testimony' and my professional work, that is the embroideries I make as an academic researcher. Although both works carry significant meaning for me, my academic work does not always have a relaxing effect. There are demanding reflections and analyses that come before doing my academic crafts. Additionally, I push myself to the limit of my abilities and seek to perform in full domination of my practice (bead-embroidery). In contrast, the textile testimony was a much freer instance, as it was an opportunity to explore and experiment with new topics and techniques without any professional constraints (Hackney, Maughan and Desmarais, 2016). Additionally, all the workshop participants were amateurs, and working together with a collaborative aim had the advantage of receiving support from everyone in the group, which was greatly encouraging, as well as calming and relaxing. Because of this free-from-pressure instance, I was able to observe and enjoy the slowness of the process of creating a piece of textile art, and reflect on an urgent sensitive topic while I was stitching, feeling that I was achieving something in the form of social activism.

\section{Textile testimony}

For my textile piece, I decided to reflect on the notion of home considering our planet and its state of climate emergency. Further, I focused on issues in Chile that contribute to this crisis. Thus, I used scraps of fabric to depict a piece of land and ocean, with an embroidered araucaria, a millenary tree protected by the largest indigenous community in Chile, the Mapuche. I also embroidered the phrase 'Mapu mew iñchiñ ta ngen-ngenkülelaiñ. Mapu may ta iñchiñ' in Mapuzugun, the language of the Mapuche; in English, it means 'The Earth 
is not ours; we belong to the Earth' (credits to 'Kimeltuwe: materials for Mapudungun'). This phrase is inspired by an eco-poem written by Chilean anti-poet Nicanor Parra, in which he claimed: 'The mistake we made was in thinking that the earth belonged to us when the fact of the matter is we're the ones who belong to the earth' (Parra, 1985). I chose to embroider the phrase in Mapuzugun in support of the Mapuche community's claim for the return of their ancestral land, considering their ultimate commitment to protecting the environment, which is essential in confronting the climate emergency.

For my arpillera, I also chose to depict the sacrifice zones in Chile, keeping in mind the city of Quintero in the fifth region, a city close to where I originally come from. In this sense, I recreated a factory chimney with poisonous fumes, using scraps of fabric and embroidery.

'Sacrifice zone' is a term coined to reflect highly industrialised geographical places, which cause severe health problems to the communities living in those areas, and severe damage to the environment (Lerner and Brown, 2012; Oceana Chile, no date). Therefore, Quintero is a city where its citizens (called Quinterinos) are constantly having to endure unacceptable carcinogenic risks due to exposure to contamination (Tapia-Gatica et al., 2019). My textile was informed by the helplessness of Quinterinos, deliberately abandoned by the Chilean government which prioritises the economy and the industry above life - a situation which is even graver considering the critical state of the climate crisis the world is currently facing.

The struggle of Quinterinos may resonate with the struggle of the Mapuche due to their efforts to protect the environment and the constant danger both communities face because of the irreparable damage that is being done to the land they inhabit.

\section{Letting go}

I tend to develop an emotional attachment to my textile artworks. This is not only because I usually find them aesthetically pleasing, but there are also complexities associated with the enormous amount of time I spend developing them, as well as the physical and emotional costs that this extreme dedication has.

As the purpose of the workshops was to create textile works that would be part of a collaborative piece, I did not develop an attachment to my creation. This does not mean that I did not put as much effort as I usually do into my professional work, but it made me reflect on different aspects of why I was creating this piece and for whom I was creating it. I saw it as a short break from my professional practice and a chance to try out a different side of stitching I was not accustomed to. More importantly, however, I saw these 'textile testimonies' as a possibility for an intimate form of activism (Corbett, 2017), that is, social activism on a smaller scale with handmade items. This activity was a great reminder of how with few materials, group support and a meaningful aim, stitching offers a simple way to tell the world about matters that are important to us, and a significant reason for letting our creations go, 
opening up new opportunities, hoping that they will help us reach more people to engage in the fight against political violence, social inequalities and the climate crisis.

\section{References}

Bacic, R. (2013) Arpilleras in contested spaces [Public lecture]. 3 September [Online]. Available at: https://cain.ulster.ac.uk/conflicttextiles/mediafiles $/ 857$ contested $\% 20$ spaces $\% 20 w i t h \% 20$ location\%20of\%20images\%20marked.pdf (Accessed: 10 February 2021).

Corbett, S. (2017) How to be a craftivist. London: Unbound.

Hackney, F., Maughan, H. and Desmarais, S. (2016) 'The power of quiet: re-making affective amateur and professional textiles agencies', Journal of Textile Design Research and Practice, 4 (1), pp. 33-62.

Hunter, C. (2019) 'The calming effects of sewing can help people express and heal themselves', The Guardian, 23 February [Online]. Available at: https://www.theguardian. com/lifeandstyle/2019/feb/23/the-calming-effects-of-sewing-can-help-people-express-andcalm-themselves?CMP $=$ share btn link (Accessed: 24 August 2020).

Lerner, P. and Brown, P. (2012) Sacrifice zones: the front lines of toxic chemical exposure in the United States. Cambridge, MA: The MIT Press.

Moulian, T. (1997) Chile actual: anatomía de un mito. Santiago de Chile: LOM Ediciones.

Moya-Raggio, E. (1984) 'Arpilleras: Chilean culture of resistance', Feminist Studies, 10 (2), pp. 277-290.

Oceana Chile (no date) Zonas de sacrificio [Online]. Available at: https://chile.oceana.org/ zonas-de-sacrificio-0 (Accessed: 10 August 2020).

Parra, N. (1985) Ecopoemas [Online]. Available at: https://www.nicanorparra.uchile.cl// antologia/ecopoemas/ecopoemas.html (Accessed: 7 August 2020).

Pöllänen, S.H. and Weissmann-Hanski, M.K. (2019) 'Hand-made well-being: textile crafts as a source of eudaimonic well-being', Journal of Leisure Research, 51 (3), pp. 348-365 [Online]. DOI: 10.1080/00222216.2019.1688738 (Accessed: 24 February 2021).

Rowinsky-Geurts, M. (2003) 'Hilando memorias: la re-configuración y transmission del discurso chileno en los tapices de la esperanza', Taller de Letras, 33, pp. 35-45. 
Shercliff, E. and Twigger Holroyd, A. (2020) 'Stitching together: participatory textile making as an emerging methodological approach to research', Journal of Arts \& Communities, 10 (1-2), pp. 5-18.

Tapia-Gatica, J., González-Miranda, I., Salgado, E., Bravo, M.A., Tessini, C., Dovletyarova, E.A., Paltseva, A.A. and Neaman, A. (2019) 'Advanced determination of the spatial gradient of human health risk and ecological risk from exposure to $\mathrm{As}, \mathrm{Cu}, \mathrm{Pb}$, and $\mathrm{Zn}$ in soils near the Ventanas Industrial Complex (Puchuncaví, Chile)', Environmental Pollution, 258, 113488 [Online]. DOI: 10.1016/j.envpol.2019.113488 (Accessed: 24 February 2021).

Wellesley-Smith, C. (2015) Slow stitch: mindful and contemplative textile art. London: Batsford. 